and those of Sim and McCraw is probably due to factors such as individual subject variation or differing experimental conditions. The most surprising finding in the aggregation studies was the inhibition of ristocetin-induced aggregation during the sustained dosing study in case 1. Lack of aggregation to ristocetin is characteristically associated with von Willebrand's disease, in which there is evidence of defective adhesion of platelets to subendothelium $^{17}$ and, in pigs, resistance to experimentally induced

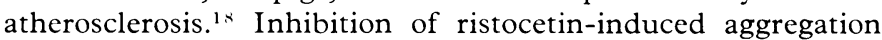
therefore suggests that DHLA may have an inhibitory effect on platelet-vessel wall interaction, a probable early event in the formation of arterial thrombi. No other features of von Willebrand's disease were detected.

Diets low in saturated fats and rich in polyunsaturated fats (predominantly linoleic acid) both lower heparin-neutralising activity $^{19}$ and reduce platelet aggregability. ${ }^{20}$ Since linoleic acid is a precursor of DHLA (fig 1 ) both these effects may be mediated through its conversion to DHLA. Such diets have also been reported to reduce mortality due to atherosclerosis, ${ }^{21}$ and partial substitution of dietary saturated fats by polyunsaturated fats has been widely recommended as a means of reducing the risk of coronary heart disease. ${ }^{22}{ }^{23}$ Perhaps small doses of DHLA may be equally if not more effective than major dietary manipulations in preventing and treating these conditions.

We thank the Special Trustees of the General Infirmary at Leeds and Roche Products Ltd for financial support; and Dr M Zuzel and Dr I R Peake for their help with the assays of heparin-neutralising activity and ristocetin cofactor. Scientific and technical contributions were made by $G$ Fieldhouse, B Griffin, $M$ Hart, J Leek, G Levell, E Morris, S Nelson, P Marples, V Menys, and A Spencer.

\section{References}

1 Willis, A L, et al, in Prostaglandins in Hematology, ed M J Silver, J B Smith, and J J Kocsis, p 371. New York, Spectrum Publications, 1977.

Rasmussen, H, and Lake, W, in Prostaglandins in Hematology, ed M J Silver, J B Smith, and J J Kocsis, p 187. New York, Spectrum Publications, 1977 .

${ }^{3}$ Emmons, P R, et al, British Medical fournal, 1967, 2, 468.

' Mustard, J F, and Packham, M A, Drugs, 1975, 9, 19

Willis, A L, et al, Prostaglandins, 1974, 8, 509.

"Davies, T, et al, Thrombosis Research, 1974, 5, 667

Donati, M B, et al, Advances in Experimental Medicine and Biology, 1972, 34, 295.

O'Brien, J R, et al, fournal of Clinical Pathology, 1975, 28, 975.

"Nath, N, Niewiarowski, S, and Joist, H H, Fournal of Laboratory and Clinical Medicine, 1973, 82, 754.

1" Willis, A L, and Weiss, H J, Prostaglandins, 1973, 4, 783.

Borchgrevink, C F, Acta Medica Scandinavica, 1960, 168, 157.

Willis, A L, Thrombosis and Haemostasis, 1977, 38, 18 .

${ }^{3}$ Smith, J B, et al, Thrombosis Research, 1974, 5, 291

${ }^{14}$ Moncada, S, Higgs, E A, and Vane, J R, Lancet, 1977, 1, 18.

${ }^{5}$ O'Brien, J R, in Recent Advances in Blood Coagulation, No 2, ed L Poller, p 241. Edinburgh, Churchill Livingstone, 1977.

${ }_{16}$ Sim, A K, and McCraw, A P, Thrombosis Research, 1977, 10, 385.

1: Tschopp, T B, Weiss, H J, and Baumgartner, H R, Fournal of Laboratory and Clinical Medicine, 1974, 83, 296.

1* Fuster, V, Bowie, E J W, and Lewis, J C, Thrombosis and Haemostasis, $1977,38,55$.

1:" O'Brien, J R, et al, Lancet, 1976, 2, 995

20 Hornstra, G, et al, Lancet, 1973, 1, 1155

${ }^{21}$ Dayton, S, et al, Circulation, 1969, 39 40, Suppl No 2.

22.2 Joint Working Party of the Roval College of Physicians of London and the British Cardiac Society, Fournal of the Royal College of Physicians of London, 1976, 10, 213.

2:3 Shaper, A G, and Marr, J W, British Medical fournal, 1977, 1, 867.

\title{
Reticulocytopenia and "absence" of red cell autoantibodies in immune haemolytic anaemia
}

\author{
U M HEGDE， E C GORDON-SMITH， SHEILA M WORLLEDGE
}

British Medical fournal, 1977, 2, 1444-1447

\section{Summary}

A raised reticulocyte count is common in patients with immune or autoimmune haemolytic anaemia, and the result of the direct antiglobulin test (DAGT) is usually positive because of IgG or IgG and complement components on the red cells. We report on three patients who had low reticulocyte counts when they were most anaemic, and in whom no red cell autoantibodies could be detected by the DAGT.

We postulate that reticulocytes may be selectively destroyed if antibodies are directed against antigenic sites on these young red cells, thus giving rise to a population of cells whose antigenic sites are poorly expressed. This theory might explain the low reticulocyte counts

Department of Haematology, Hammersmith Hospital and Royal Postgraduate Medical School, Ducane Road, London W12 0HS

U M HEGDE, MB, MRCPATH, senior registrar (now consultant haematologist, King Edward Memorial Hospital, Ealing, London W13 9NU)

E C GORDON-SMITH, MSC, MRCP, senior lecturer

SHEILA M WORLLEDGE, MRCP, FRCPATH, reader and the "absence" of antibodies (as tested by the DAGT) in such patients. Radioisotopic studies with ${ }^{51} \mathrm{Cr}$ and ${ }^{59} \mathrm{Fe}$ may provide useful information on the rate and sites of red cell destruction.

\section{Introduction}

Increased destruction of red cells in "warm" immune or autoimmune haemolytic anaemia (AIHA) is commonly associated with a positive direct antiglobulin test (DAGT) result, usually because of the presence of either IgG alone or IgG and complement on the surface of the red cells. Some patients have all the clinical features of AIHA, but no antibody can be detected on the red cells by the direct antiglobulin test. ${ }^{1-3}$ By using the sensitive antiglobulin consumption technique, however, small quantities of antibody belonging to the IgG class have been shown on the red cells of some patients with a negative DAGT result. ${ }^{1}$ Most patients with AIHA have a raised reticulocyte count at presentation-a reflection of the high erythroid turnover that occurs to compensate for the anaemia and anoxaemia. Crosby and Rappaport, ${ }^{5}$ however, noted the occurrence of reticulocytopenia in AIHA, and Pirofsky ${ }^{3}$ also reported a low reticulocyte count in some patients with this disorder whose bone-marrow aspirate was normal or hyperplastic.

We report on three patients who had haemolytic anaemia with some unusual features. Neither IgG antibodies nor complement 
components could be shown on the red cells in one of these patients, and only complement components were found in the other two. All three patients had a low reticulocyte count when they were most anaemic. We used radioisotope studies to investigate the rate and sites of red cell destruction. Haematological methods used are those described by Dacie and Lewis. ${ }^{6}$

\section{Case reports}

CASE 1

The patient was 9 years old when she first presented in December 1975 with a short history of jaundice (see fig 1). She was pale and jaundiced, and had no lymphadenopathy or hepatosplenomegaly. $\mathrm{ml}$ ), chiefly unconjugated. Gastric parietal cell antibody titre was weakly positive; antibody titre to mycoplasma was consistently $<1 / 16$. Bone marrow aspiration showed considerable erythroid hyperplasia with many more polychromatic red cells than in the peripheral blood film. Erythrophagocytosis was conspicuous.

${ }^{59} \mathrm{Fe}$ studies (fig 2) showed a rapid accumulation of radioactivity over the spleen after 24 hours, concurrent with a fall in activity over the sacrum. We interpreted this as representing destruction of young red cells by the spleen, and thought it might explain the peripheral blood reticulocytopenia, even though many polychromatic cells were seen in the bone marrow aspirate. A splenectomy was performed because of the persistent haemolysis and transfusion requirements. After a stormy postoperative period, she made a good recovery with a reticulocytosis of $15^{\circ} \ldots$. Histological examination of the spleen showed striking erythrophagocytosis, but no phagocytosis of neutrophils or platelets. The patient remained in complete remission 18 months after splenectomy.

CASE 2

A man aged 41 first presented in October 1967 with a short history of lassitude (see fig 3). He was anaemic, and had a large spleen but no hepatomegaly or lymphadenopathy. Investigations showed: $\mathrm{Hb} 5.6$ $\mathrm{g} / \mathrm{dl}$, reticulocytes $3^{\circ}{ }_{0}$; WCC $3: 10^{9} / 1$; result of DAGT negative.

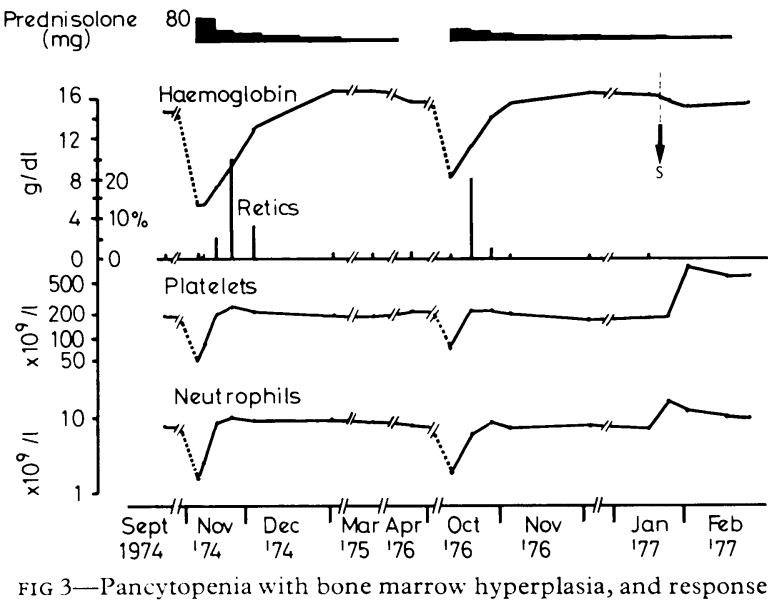

to treatment with prednisolone (case 2 ). S splenectomy.

Bone marrow aspiration showed active normoblastic marrow. Serum bilirubin was $46 \mu \mathrm{mol} 1(2.7 \mathrm{mg} 100 \mathrm{ml})$, chiefly unconjugated. He was transfused and started on prednisolone, to which he responded very well. He relapsed a year later, and this time the DAGT gave a positive result-complement components only were present on the red cells. No antibody could be eluted, but free in the serum there was an antibody that agglutinated (titre 164 ) and lysed (titre 1/10) only enzymetreated red cells at $37 \mathrm{C}$. He remitted satisfactorily again after steroid treatment, and remained well until November 1974 when the spleen was palpable $4 \mathrm{~cm}$ below the costal margin.

Investigations showed: $\mathrm{Hb} 5.7 \mathrm{~g} / \mathrm{dl}$; reticulocytes $0.5^{\prime \prime}$; WCC $2.6 \quad 10^{9} 1$ neutrophils $1.5 \quad 10^{9} 1$ ); platelets $47 \quad 10^{9} 1$. Bone marrow aspiration showed erythroid hyperplasia. DAGT result was positive, but only because of complement components on the red cells; no antibody was eluted from the red cells. Cold agglutination titre was normal. Serum bilirubin was $66 \mu \mathrm{mol} 1(3.9 \mathrm{mg} 100 \mathrm{ml})$, chictly unconjugated; serum immunoglobulins were normal, apart from a slightly low IgA concentration. All other biochemical tests gave normal results, as did a lymphangiogram performed to exclude an occult lymphoma.

He was started on prednisolone $80 \mathrm{mg}$ daily, and this was associated with a dramatic clinical and haematological recovery. The result of the DAGT, however, remained weakly positive due to complement only.

Fe studies showed a quick clearance of iron $(t ! 20$ min) with uptake of the label by the bone marrow. Over the next 72 hours this activity over the sacrum fell, associated with rapid accumulation over the spleen. In October 1976 the $\mathrm{Hb}$ dropped to $8.0 \mathrm{~g} \mathrm{dl}$, again with reticulocytopenia, neutropenia, and thrombocytopenia. He responded satisfactorily yet again to prednisolone, with a reticulocytosis of $21^{\circ} \mathrm{o}$ normal, as were results of haemoglobin electrophoresis and glucose phosphate dehydrogenase assay. Biochemical profile was normal, except for a serum bilirubin concentration of $80 \mu \mathrm{mol} 1(4.7 \mathrm{mg} 100$ 
and a normal neutrophil and platelet count. In December 1976 he complained of abdominal pain, which was shown to be caused by gall stones. A cholecystectomy and splenectomy was performed in January 1977, and recovery from surgery was uneventful. Histological examination of the spleen showed nothing relevant.

\section{CASE 3}

A boy aged 13 first presented in March 1975 with a short history of the symptoms of anaemia (see fig 4). He was pale and jaundiced, but had no lymphadenopathy or hepatosplenomegaly. Investigations showed: $\mathrm{Hb} 2.9 \mathrm{~g} \mathrm{dl}$; reticulocytes $3^{\prime \prime}$ "; WCC 16 . $10^{9} 1$; platelets 140 $10^{9} / 1$; result of DAGT negative; antibody titres to mycoplasma, toxoplasma, cytomegalovirus, and leptospira were not raised; result of Paul-Bunnell screening test was negative; liver function was mildly impaired. He was transfused and started on prednisolone $60 \mathrm{mg}$ daily, which maintained the $\mathrm{Hb}$ concentration at $10.0 \mathrm{~g} \mathrm{dl}$ with a good reticulocyte response. He became severely anaemic when the dose of prednisolone was reduced to $20 \mathrm{mg}$ daily. The survival of red cells labelled with " $\mathrm{Cr}$ was greatly reduced $(t \cdot 2 \cdot 3$ days, normal 27-33 days), with a high early splenic uptake of the isotope. A splenectomy was carried out uneventfully in mid-April 1975. Soon after surgery, however, a further haemolytic crisis took place while on prednisolone $20 \mathrm{mg}$ daily, and he was transferred to Hammersmith Hospital after blood transfusions.

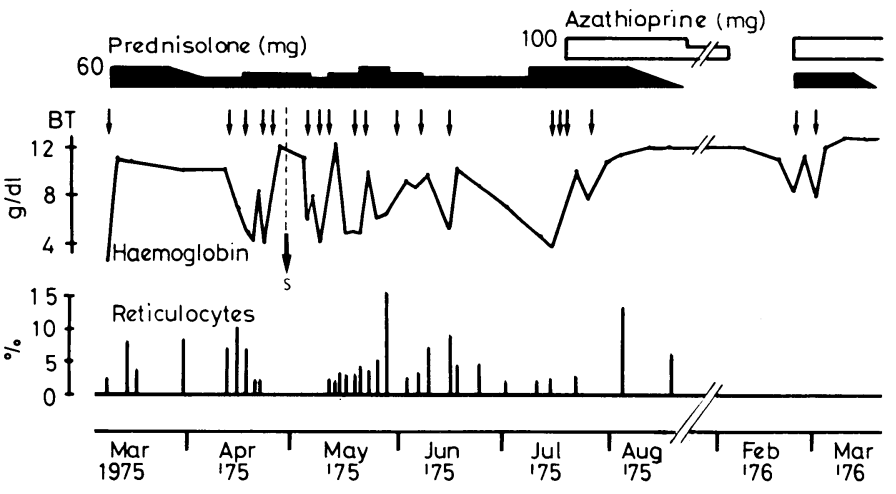

FIG 4-Severe haemolysis and reticulocytopenia when reduction of steroid doses was attempted, and recovery after treatment with azathioprine (case 3 ). $S$ - splenectomy; BT = blood transfusion.

Investigations showed: $\mathrm{Hb} 11.8 \mathrm{~g} / \mathrm{dl}$ (after transfusion); reticulocytes $3.4^{\prime \prime}{ }_{0}$; WCC $10 \cdot 6 \times 10^{9} / 1$; platelets $400 \times 10^{9} / 1$. Blood film showed red cell autoagglutination and post-splenectomy changes. Result of DAGT was weakly positive, because complement only was present on the surface of the red cells. No antibody was eluted from the red cells and red cell autoantibodies were absent in serum. Cold agglutinin titre was $1 / 16$ at $4 \mathrm{C}$. Acidified serum lysis, sucrose lysis, and cold antibody lysis tests gave negative results, as did screening tests for urinary porphyrins. Plasma bilirubin was $84 \mu \mathrm{mol} / 1(4.9 \mathrm{mg} 100 \mathrm{ml})$. Serum immunoglobulins, serum copper, and serum caeruloplasmin were all normal. No tissue autoantibodies were detected. Bone marrow aspiration showed marked erythroid hyperplasia and erythrophagocytosis.

The dose of prednisolone was increased to $80 \mathrm{mg}$ daily and the reticulocyte count, which had consistently been about $3^{\circ}$ " at the height of haemolysis, rose to $21^{\circ}$... This remission was, however, short lived, and the $\mathrm{Hb}$ fell to $3.5 \mathrm{~g} / \mathrm{dl}$ with a reticulocyte count of only $3{ }^{\circ}$ when the dose of prednisolone was reduced to $30 \mathrm{mg}$ daily. He was then started on azathioprine $100 \mathrm{mg}$ daily, and three weeks later his reticulocyte count rose to $18^{\prime \prime}$ ". He remained in good remission without evidence of haemolysis for seven months, but relapsed again in March 1976 soon after azathioprine was withdrawn. He was therefore restarted on azathioprine, and $\mathrm{Hb}$ concentrations remained satisfactory.

\section{Discussion}

Various congenital haemolytic anaemias, paroxysmal nocturnal haemoglobinuria (PNH), paroxysmal cold hae- moglobinuria $(\mathrm{PCH})$, and drug-induced anaemias were all excluded in the patients reported here. Despite the failure of the DAGT to show antibody on the red cells of these patients the mechanism of accelerated red cell destruction was probably immune. The demonstration by Gilliland et al ${ }^{1}$ of small but abnormal amounts of IgG antibody on the red cells of patients with Coombs-negative AIHA shows that active haemolysis may occur with concentrations of antibody well below the lower limit of sensitivity of the conventional antiglobulin test. Furthermore, these workers ${ }^{7}$ found abnormal amounts of IgG antibody by use of the antiglobulin consumption technique in 13 of 16 patients in whom only complement components were detected by the DAGT. They concluded that in many patients with AIHA in whom the DAGT shows only cell-bound complement, this fixation of complement had been mediated in vivo by trace amounts of IgG red cell autoantibody.

The clinical course of our patients was similar to that commonly seen in AIHA. Although the third patient did not remain in remission after splenectomy, or even while on relatively high doses of steroids, he did respond to the immunosuppressive agent azathioprine on two occasions, and indeed relapsed when this drug was withdrawn. The second patient developed neutropenia, thrombocytopenia, and reticulocytopenia simultaneously while in relapse. The association of neutropenia with AIHA is uncommon, ${ }^{x}$ unlike that of thrombocytopenia." Nevertheless, pancytopenia in AIHA has been noticed by other workers, ${ }^{3} 1111$ and it has been suggested ${ }^{3}$ that single or multiple antibody formation may result in concurrent thrombocytopenia, neutropenia, or even pancytopenia in patients with AIHA. Erythrophagocytosis, often seen in AIHA, was conspicuous in the bonemarrow aspirates in patients 1 and 3 , and this may well have followed coating of red cells by trace amounts of IgG. ${ }^{12} 11$ The remission after splenectomy in the first patient reflects the high sensitivity of the spleen to relatively low-density proteincoating in mediating red cell destruction.

The bone marrow is invariably hyperplastic to compensate for the shortened red-cell lifespan in AIHA. It is therefore remarkable that our patients had low reticulocyte counts at presentation, when their bone marrow showed normal or even increased numbers of erythroid precursors. Pirofsky ${ }^{3}$ suggested that in AIHA associated with other diseases such as lymphoma the bone marrow's capacity to increase under stress was limited. No underlying disease, however, was found in our patients. The failure to detect antibody and the reticulocytopenia is difficult to explain. Auto-antibodies might have been directed against reticulocytes. While the nature of the antibody and the antigenic site is speculative in our patients, experimental evidence suggests that antigenic determinants on erythrocyte precursors can react with red cell autoantibodies. ${ }^{16} 17$ If the antigenic sites were strongly expressed on a large population of young red cells or reticulocytes, these cells would be destroyed, giving rise to an accumulation of cells on which these antigenic sites were poorly expressed. The concentration of antibody on these surviving cells could therefore be too low to be detected by the DAGT.

Conventionally, ${ }^{51} \mathrm{Cr}$ has been used to study red cell survival in AIHA, and surface counting over the spleen and liver often gives information on the rate and sites of red-cell destruction. ${ }^{1 \times 1.9}$ Ideally, only the patient's own cells should be labelled. This is often impossible in patients who haemolyse at an extremely high rate and who require repeated blood transfusions. Also, as discussed above, cells which are heavily coated with autoantibody will be selectively and rapidly destroyed, leading to an accumulation of cells for which the antibody has low affinity. ${ }^{51} \mathrm{Cr}$ studies using the patient's own cells may therefore measure the survival of this longer-lived population. Our experience with patients 1 and 2 suggests that ferrokinetic studies with ${ }^{59} \mathrm{Fe}$ may be useful if there are clinical signs strongly suggestive of accelerated cell destruction. This is particularly so when the bone marrow is shown to have at least normal numbers of erythroid precursors, since this technique will label an unselected cohort of the patient's own cells. The rapid accumulation of the isotope 
in the spleen or liver or both after an interval of 24-48 hours, together with a fall in marrow radioactivity, can only be due to trapping and subsequent destruction of the patient's own red cells. Although the results thus obtained are only qualitative, this aspect of the investigation of haemolytic anaemia warrants further study.

We thank Professor Sir John Dacie FRS for his help and constructive criticism and Drs A Dawson, P D Robertson, and E C B Keat for allowing us to study and report details of these patients.

\section{References}

'Evans, R S, and Weiser, R S, Archizes of Internal Medicine, 1957, 100, 371. Worlledge, S M, and Blajchman, M A, British fournal of Haematology, 1972, 23, (suppl), 61.

"Pirofsky, B, Autoimmunization and the Autoimmune Haemolytic Anemias. Baltimore, Williams and Wilkins, 1969.

' Gilliland, B C, Baxter, E, and Evans, R S, New England fournal of Medicine, 1971, 285, 252.
${ }^{5}$ Crosby, W H, and Rappaport, H, Blood, 1956, 11, 929.

'Dacie, J V, and Lewis, S M, Practical Haematology, 5th edn. London, Churchill, 1975.

Gilliland, B C, Turner, E R, and Evans, R S, Fournal of Clinical Investigation, 1970, 40, 898.

* Dacie, J V, The Haemolytic Anaemias: Congenital and Acquired, 2nd edn. London, Churchill, 1962.

"Evans, R S, and Duane, R T, Blood, 1949, 4, 1196.

${ }^{10}$ Fisher, J A, Quarterly fournal of Medicine, 1947, 16, 245.

${ }^{11}$ Evans, R S, et al, Archives of Internal Medicine, 1951, 87, 48.

12. Brown, D L, Series Haematologica, 1974, 7, 348.

${ }^{13}$ Engelfriet, C P, et al, Series Haematologica, 1974, 7, 328.

14 Dacie, J V, Archives of Internal Medicine, 1975, 135, 1293.

15 Rosse, W F, Fournal of Clinical Investigation, 1971, 50, 534.

${ }^{16}$ Pisciotta, A V, and Hinz, J E, Proceedings of the Society of Experimental and Biological Medicine, 1956, 91, 356.

17 Yunis, J J, and Yunis, E, Blood, 1963, 22, 53.

${ }^{1 *}$ Hughes-Jones, N C, and Szur, L, British fournal of Haematology, 1957, 3, 320.

1: Williams, E D, et al, fournal of Laboratory and Clinical Medicine, 1974, 84, 134.

(Accepted 3 October 1977)

\title{
Doxorubicin cardiotoxicity: possible role of digoxin in its prevention
}

\author{
D GUTHRIE, A L GIBSON
}

British Medical fournal, 1977, 2, 1447-1449

out to determine whether it was possible to continue safely beyond $550 \mathrm{mg} / \mathrm{m}^{2}$ with the use of cardiac glycosides.

\section{Summary}

Twenty-nine patients with gynaecological cancers who received over $400 \mathrm{mg}$ of doxorubicin were monitored electrocardiographically to determine whether cardiac glycosides countered the adverse effects of high total doses of doxorubicin. Minor electrocardiographical changes were noted in five out of six patients who were not receiving a cardiac glycoside and four out of six who were receiving ouabain, and none of the 16 who were receiving digoxin. One other patient on digoxin stopped taking it and developed cardiomyopathy. One patient on ouabain also developed cardiomyopathy. So far nine patients on digoxin have received between 550 and 1000 $\mathrm{mg} / \mathrm{m}^{2}$ of doxorubicin without ill effect.

Cardiac glycosides are thought to prevent doxorubicin cardiomyopathy by competitively inhibiting doxorubicin at its receptor sites, but ouabain has a much shorter half life than doxorubicin and its metabolites and so is less effective than digoxin.

\section{Introduction}

Doxorubicin (adriamycin) is a cytotoxic antibiotic widely used in the treatment of malignancy. Its use has been limited, however, by the high incidence of fatal cardiomyopathy that occurs with large cumulative doses. ${ }^{1}$ The manufacturers recommend that the maximum cumulative dose should not exceed $550 \mathrm{mg} / \mathrm{m}^{2}$. After work reported on in 1974 by Lenaz² we set

Queen Elizabeth Hospital, Gateshead

D GUTHRIE, MB, MRCOG, research fellow, department of gynaecological oncology

A L GIBSON, MA, MRCP, consultant physician

\section{Patients and methods}

One of us (DG) has treated many patients with cytotoxic regimens that have included doxorubicin. Among these were 29 who had a total dose of doxorubicin of over $400 \mathrm{mg}$. These patients all had advanced gynaecological cancer and fell into three groups on the basis of their cardiac glycoside therapy: six patients had no cardiac glycoside; six were given ouabain $0.25 \mathrm{mg}$ intravenously 15 minutes before each dose of doxorubicin; and 17 were given digoxin $0.25 \mathrm{mg}$ day starting seven days before the first dose of doxorubicin and continuing until four weeks after the cessation of all cytotoxic treatment. The dose of digoxin was reduced only when electrocardiograms (ECGs) showed evidence of digoxin toxicity.

All patients had an ECG recorded before treatment and every three or four weeks after a total dose of $400 \mathrm{mg}$ doxorubicin had been reached. All ECGs were read blind by one of us (ALG) who knew only that a patient was receiving a cardiac glycoside but not which one. All three groups of patients were comparable as regards age (mean 54 years), blood pressure, and other factors concerning the cardiovascular system. There were no diabetic patients in the series, and no patient had any history of coronary artery disease.

\section{Results}

Minor ECG changes were noted in five of the six patients who were not taking cardiac glycosides and four of the six patients taking ouabain. The only changes noted in the digoxin group were those relating to the digoxin itself, except in one patient who stopped taking her digoxin and later developed cardiomyopathy. One other patient, who was taking ouabain, also developed cardiomyopathy. The case histories of these two patients are given below.

Statistical analysis comparing those receiving digoxin with those receiving other treatment, using a $\%^{2}$ test with Yates's correction for continuity, ${ }^{3}$ showed a highly significant difference $(P<0 \cdot 001)$. The patient who took herself off digoxin was omitted for the purposes of statistical analysis.

In the group not receiving cardiac glycosides doxorubicin treatment was stopped at $550 \mathrm{mg} / \mathrm{m}^{2}$. Two of the patients receiving ouabain had over $500 \mathrm{mg} / \mathrm{m}^{2}$ of doxorubicin: one had $600 \mathrm{mg} / \mathrm{m}^{2}$ and the other, who developed cardiomyopathy, had $1000 \mathrm{mg} / \mathrm{m}^{2}$. 